\title{
Sp I Contributes to Radioresistance of Cervical Cancer Through Targeting G2/M Cell Cycle Checkpoint CDKI [Corrigendum]
}

Deng YR, Chen XJ, Chen W, et al. Cancer Manag Res. 2019;11:5835-5844.

The authors have advised due to an error at the time of figure assembly, Figure 3A on page 5840 is incorrect. The correct Figure 3 is shown below.
The authors apologize for this error and advise it does not affect the results of the paper.
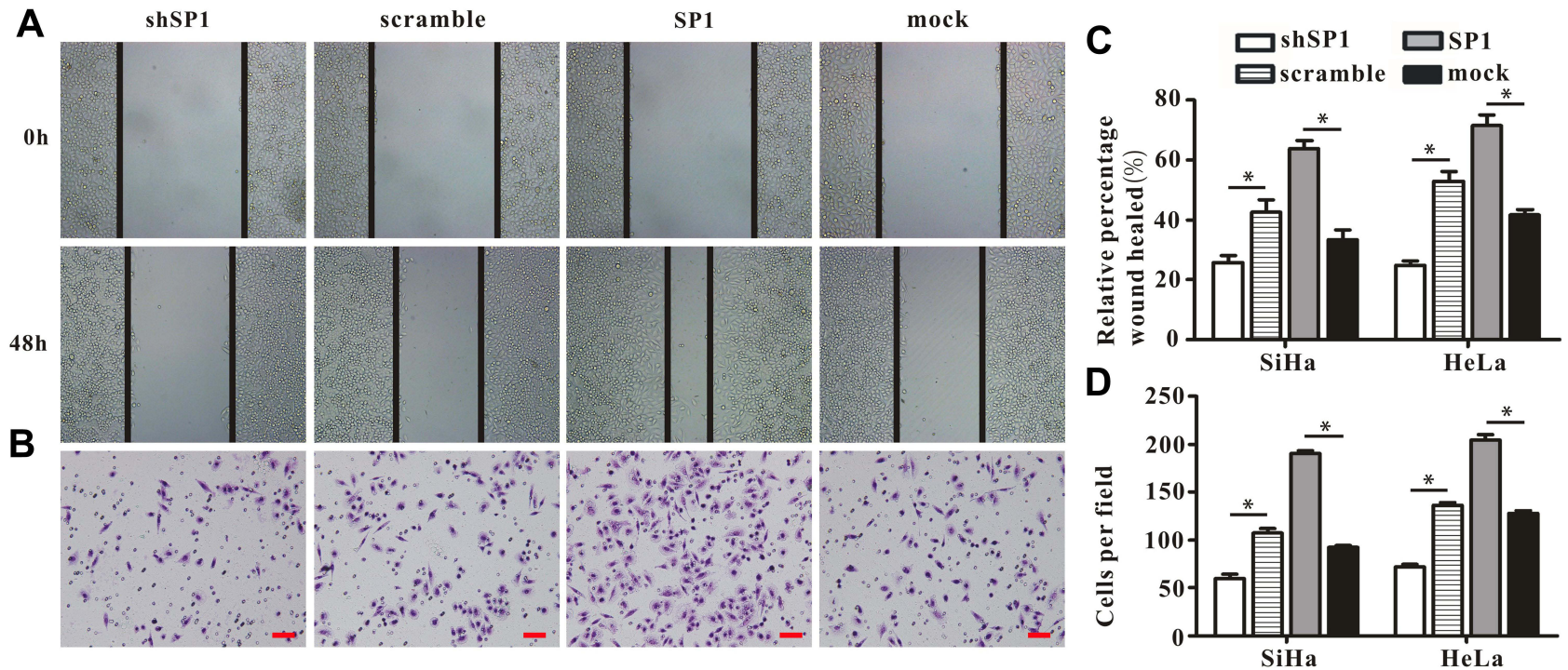

Figure $3 \mathrm{Spl}$ promotes migration and invasion of cervical cancer cells in response to radiation. (A) Wound-healing assay of the four groups in cervical cancer cells. (B) Transwell migration assay of the four groups in cervical cancer cells (scale bar, $50 \mu \mathrm{m}$ ). (C) Cell migration was quantified as percentage of wound-healed area. (D) Average number of invading cells per field from three independent experiments. Data represent means \pm SD of five randomly selected areas. $* P<0.05$.

\section{Publish your work in this journal}

Cancer Management and Research is an international, peer-reviewed open access journal focusing on cancer research and the optimal use of preventative and integrated treatment interventions to achieve improved outcomes, enhanced survival and quality of life for the cancer patient.
The manuscript management system is completely online and includes a very quick and fair peer-review system, which is all easy to use. Visit http://www.dovepress.com/testimonials.php to read real quotes from published authors. 